\title{
The Role of Employee Human Resources Attribution on Developing Psychological Contract and Turnover Intention in Hong Kong \\ Kong Chui Shan ${ }^{1}$ \\ ${ }^{1}$ Aston University, United Kingdom
}

kongchuishanjanet@gmail.com

\begin{abstract}
The purpose of the study is to illustrate how the human resources $(H R)$ practices affecting the employee outcomes, this study used the concept from social and behavior science with HR management, which were attribution theory and psychological contract, to show how employees perceived the information differently. It further suggested how the process affected the performance of the employees, which illustrated through presenting their turnover intention in this model. In order to test the model, a quantitative survey was designed and conducted through snowball sampling. Multiple linear regression analysis model was used in this study to examine the data sets and tested the hypotheses. The result of this study showed how employees perceived the information could dramatically affect their reaction, as well as employee outcome. Furthermore, this study suggested that relational and transactional psychological contract was not a distinct concept, which subverted the past research regarding the types of psychological contract. This study could be used in operation management as the managers should pay attention of how they designed the HR practices could directly affect the employee outcomes and productivity. Limited research focused on the process operating in employees mind and the antecedents of psychological contract leading to certain employee outcomes. This study not only filled up the research gap but also presented the employee attribution and psychological contract concept in a complete manner by linking the variables in the model.

Keywords: employee attribution, psychological contract, turnover intention, black box theory
\end{abstract}

JEL $\quad$ : M12

DOI : :10.24002/kinerja.v24i2.3697

Received : 03/26/2020 Reviewed: 07/10/20 Final Version: 09/23/2020 


\section{INTRODUCTION}

Human resources (HR) researchers found that HR attribution could be a helpful framework for understanding how employee subjective interpretation associated with the performance of an organisation. Since HR was one of the communications and connection methods between two parties in the employment relationship, HR practices were always recognised as the use of manpower, as a kind of resources, to drive the success of an organisation (Mazzei, Flynn \& Haynie, 2016; Wright \& Gardner, 2003). Employee HR attribution was likely to set the scene of how employees perceived the HR practices and how they would react (Bowen \& Ostroff, 2004). To exert the desired effects from the employees, organisations in practice should pay attention on how the assumption and perception of an individual affected employee outcomes (Hesslow, 2002), since the employees perceived and interpreted subjectively towards the HR practices (Nishii, Lepak \& Schneider, 2008). Savaneviciene and Stankeviciute (2010) further pointed out that "how" and "why" the linkage of HR and organisational performance operated should be answered to understand the content of the social exchange process and shed a light to the "black box" theory in academic field.

Despite of these arguments, the core idea of this study is how the employees respond attitudinally and behaviourally based on the HR attribution. While some researchers focused on various employee outcomes (i.e. commitment, engagement, and job satisfaction), this study will pay attention on turnover intention and psychological contract as intervening variables. Turnover is one of employee outcomes most organisations want to prevent or reduce. On the other hand, psychological contract is well known as the social contract shaping the employment relationship, and as a social exchange concept of the expectation between both parties of the contract. As the construction of employees' attributions and psychological contracts is based on the perception of employees, it is hard to change their mind, but the employers can find a way to cooperate with them. HR department could take the framework as a reference in designing HR practices, as this study was designed to understand the correlation between employee HR attribution, psychological contract and turnover intention, as an employee outcome. Also, it can clear the air about the "black box" theory and give further understanding of human behaviorism. Hence, this study will bring a significant effect in the research field, by predicting the types of psychological contract and turnover intention through the framework of HR attribution. Also, as limited studies about HR and psychological contract have been conducted in Asia, this study was conducted in Hong Kong to fill up the gap in diversity. 


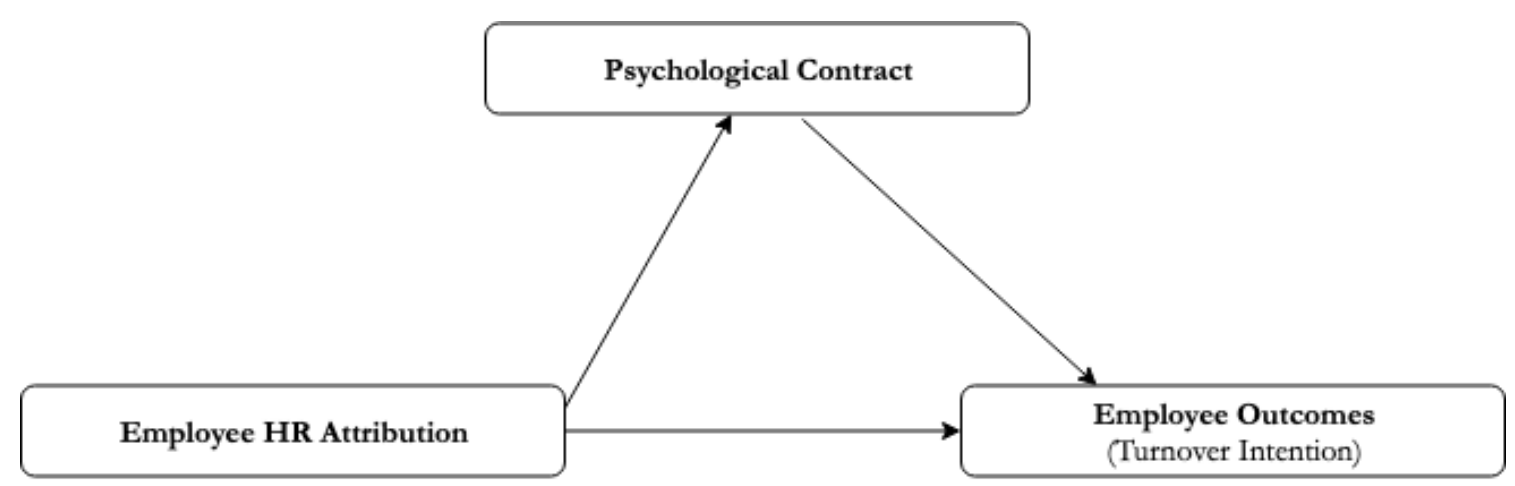

Figure 1. The hypothesized model - HR attribution \& turnover intention

\section{LITERATURE REVIEW}

\subsection{HR Attribution}

In human resources management (HRM), Nishii, Lepak and Schneider (2008) built the first framework using attribution, a social psychology concept, providing reasons why HR practices were essential. Interestingly, employee behaviour was actually caused by various factors, while people did think that they just reacted based on what kind of information they received and how they predicted the future (Jones \& Davis, 1965). Therefore, the employees would behave according to their assumption and perception of that. How people interpreted the causation would determine their reaction and response (Kelley \& Michela, 1980). As a matter of fact, HR practices were designed for certain objectives, and how well the employee understood that would greatly affect their effectiveness and outcome (Koys, 1988; 1991). Given the competitive labour market, employers obviously were willing to show the attractiveness of their organisations through HR practices to attract and retain the employees (Highhouse et al., 1999). HR practices, as the antecedents of the HR attribution, would be perceived and received in either human aspects (i.e. recruitment, co-workers and managers) or administration aspects (i.e. performance review and training) (Guest \& Conway, 2002).

\subsection{HR attribution and turnover intention}

The problem of turnover intention never stopped catching people's attention, especially when it had continued to plague organisations for decades. HRM, conventionally, played an important role in influencing employee outcomes, including turnover intention. Recent investigation attempted to find the potential predictors of turnover intention (Ballou, 2013; Van De Voorde \& Beijer, 2015), while HR attribution was suggested as the predictor variable in this study. Employees 
tended to stay longer in the organisation when they felt a sense of belonging and accomplishment. Huselid (1995) further pointed out that the HR practices related to employee promotion and retention had negative relationship with turnover intention, while HR strategies related to training or long-term service skills had positive relationship with long-term employment relationship (Arthur, 2001). It was suggested that the employees might have the HR attribution that the organisation aimed to enhance the service skills of an employee (Nishii, Lepak \& Schneider, 2008). In contrast, some employees possibly had an idea that the organisation tended to get most of the works out of employees, so they were likely to have lower job engagement and motivation (Arthur, 1994; Bamberger, Biron \& Meshoulam, 2014). Hence, the following hypotheses were proposed:

Hypothesis 1: Attribution that HR practices which are designed for enhancing the service quality will be negatively related to turnover intention

Hypothesis 2: Attribution that HR practices which are designed for getting the most work out of employees will be positively related to turnover intention

More or less, an employment relationship was not only a social exchange process, but also based on economic transaction between two parties that base compensation would be the basic criterion and the bottom line of expectation. Different from the base pay, rewards and bonus pay could be considered as one of the HR strategies to retain the employees, resulting in a long-term employment relationship. On top of that, indirect compensation, such as health care, retirement plans and family-oriented support, was commonly used as a method to retain employees (Davila \& Elvira, 2007). Specifically saying, it was expected that the employees had a higher level in job satisfaction and organisational commitment when organisation promoted employees' well-being and provided welfare policy as psychic income to the employees (Oja, Wear, \& Clopton, 2018; Sturges et al., 2005). To a certain extent, the organisation could control employees' perceptions and expectation by sending a signal of how the organisation cared about the employees through HRM. Thus, the following hypotheses were proposed:

Hypothesis 3: Attribution that HR practices which are designed for keeping the costs down will be positively related to turnover intention

Hypothesis 4: Attribution that HR practices which are designed for promoting employee well-being will be negatively related to turnover intention

Apart from the internal attributions related to the strategies of an organisation, the external attributions that HRM could not control were the social cues, the environment and union-and-law requirements. Indeed, some HR practices were designed to fulfil the basic union and regulation requirement. However, it was arguable whether external attribution attribution had relationship with the turnover intention. Hence, the following hypothesis was suggested: 
Hypothesis 5: Attribution that HR practices which are designed for fulfilling the union/regulation requests will be unrelated to turnover intention

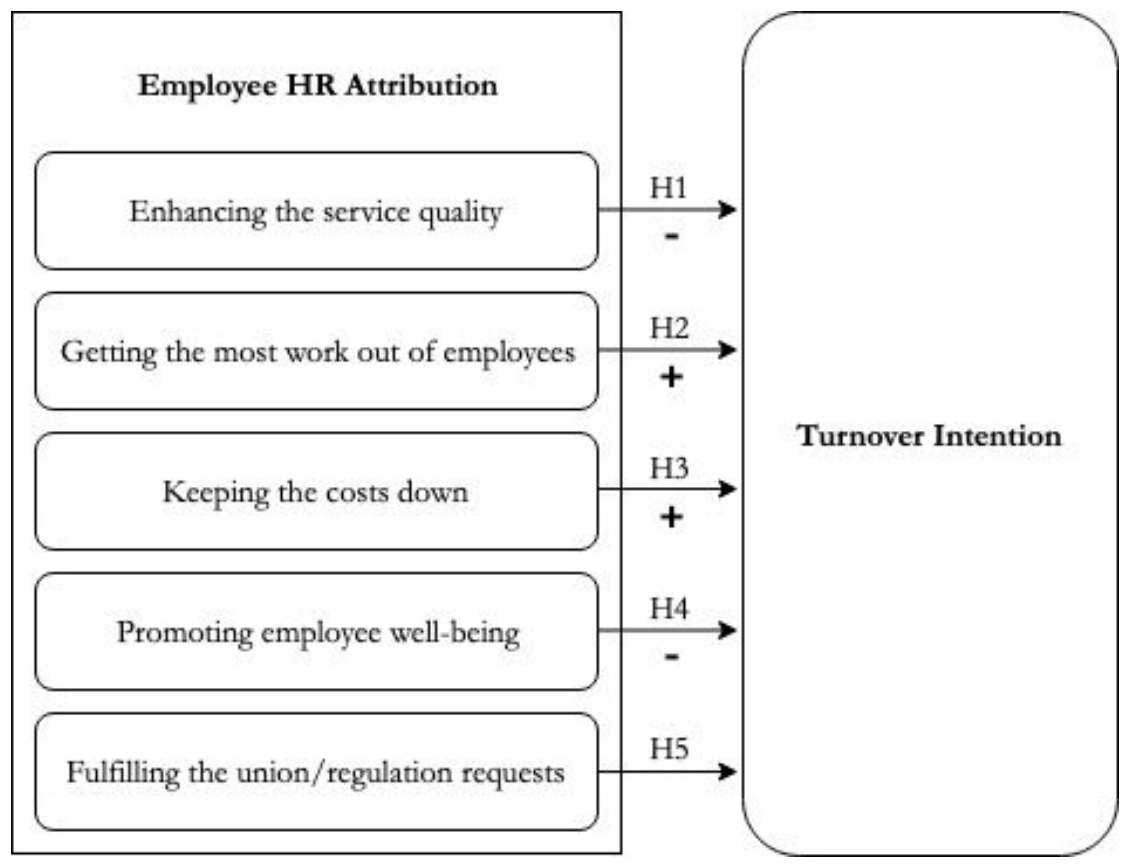

Figure 2. The hypothesized model - HR attribution \& turnover intention

\subsection{Psychological contract}

Psychological contract was a concept of how employees and employers perceived their employment relationship. Unlike a written contract of employment, psychological contract was a set of individual perceptions built on exclusively subjective viewpoints by both parties (Rousseau, 1989). It could be changed casually and secretly without any permission of the contract parties. Therefore, it was extremely difficult to determine at what point the promises were negotiated and made (Guest, 2004; Rousseau, 1995). In this study, the two main types of psychological contract-relational contracts and transactional contracts, would be discussed.

Relational contracts were based on trust and loyalty, so the employees tended to focus more on socio-emotional elements (Morrison \& Robinson, 1997; Rousseau, 2004). Generally speaking, employees with relational psychological contract would normally be expected to have a longer employment relationship, higher level in organisational commitment and organisational engagement (Antonaki \& Trivellas, 2014; Knights \& Kennedy, 2005). So, they were willing to put effort on the tasks and took risks, while they sought for job promotion and job security in return.

Transactional contracts were based on wages and bonus rather than emotional linkage to the employers (Rousseau, 2004). The employees tended to consider the 
employment as a short-term relationship. As their subjective expectations were likely related to the economic transaction with the employers, failure of delivery of that induced an immediate reaction, such as a high level of quitting (Ballou, 2013).

\subsection{HR attribution and types of psychological contract}

Psychological contract was a cognitive model to address how employees and employers interacted with each other. Cullinane \& Dundon (2006) described psychological contract as a "social exchange interaction" rather than a "contract" as it was a two-way social process. To interact with the employees, the most common method is either to communicate directly or through HRM. Since the construction of an individual perception included various factors, there was nearly no way to understand how psychological contract was operated in a person's mind. By all means, it was an analytic nightmare as there was no valid measuring method. To understand the expectation of employee, this study aimed to used HR attribution to explore how HRM impacted employees' perception.

Davila and Elvira (2007) suggested that performance appraisal system was widely used as a method leading employee achieve higher by assessing employees' performance and giving feedback for improvement. They further pointed out that the managers who gave harsh feedback would be enhancing the formation of the transactional psychological contract; on the contrary, the managers who went easy on the performance evaluations would be beneficial to the formation of the relational psychological contract, as they perceived that as caring. Although every employee deserved a fair and objective feedback, no matter whether it was positive or negative, how employees perceived that could be totally different from the intentions of managers. When the employers used the feedback system to encourage them to perform better, by sending a willingness to reward them based on their effort, employees were expected to have the HR attribution that employers wanted to enhance the service quality by motivating them. In contrast, other employees might have the attribution that the same HR strategies aimed to get most work out of the employees without any additional costs (Deckop, Mangel, \& Cirka, 1999). Although reward systems could be perceived as being wanted by the organisation, which would lead to the formation of a long-term employment relationship, it would be unlikely that the HR attribution, getting most work out of the employees, would enhance the development of relational psychological contract. Thus, the following hypotheses were proposed:

Hypothesis 6a: Attribution that HR practices which are designed for enhancing the service quality will be positively related to relational psychological contract

Hypothesis 6b: Attribution that HR practices which are designed for enhancing the service quality will be negatively related to transactional psychological contract 
Hypothesis 7a: Attribution that HR practices which are designed for getting the most work out of the employees will be negatively related to relational psychological contract

Hypothesis 7b: Attribution that HR practices which are designed for getting the most work out of the employees will be positively related to transactional psychological contract

At the beginning of an employment relationship, the employer needed to be aware of the messages delivered to the applicant. Employees would perceive whether they were valued by the organisations based on training expenditure (Suazo et al., 2009). If training programmes were offered and promises were made, employees would expect a long-term employment relationship with their organisations. Arthur (2001) further suggested that if probationary period was mentioned during the recruitment process, employees would expect more in compensation system, after the completion of the probationary period. To a certain degree, employees who wished for a long-term employment relationship would take the compensation and training costs as the investments from employers encouraging them to achieve higher in the near future.

Hypothesis 8a: Attribution that HR practices which are designed for keeping the costs down will be negatively related to relational psychological contract

Hypothesis 8b: Attribution that HR practices which are designed for keeping the costs down will be positively related to transactional psychological contract

In contrast, organisations which were relationship oriented were likely to present HR strategies related to family-oriented welfare policy, reward and bonus. Different from reducing the costs, those HR strategies which focused on retaining the talents and employees were highly associated with long-term employment relationship (Davila \& Elvira, 2007). Promoting the employee's well-beings through HRM, such as work-life balance, would be seen as offereing a long-term employment relationship. Thus, the following hypotheses were proposed:

Hypothesis 9a: Attribution that HR practices which are designed for promoting employee well-being will be positively related to relational psychological contract

Hypothesis 9b: Attribution that HR practices which are designed for promoting employee well-being will be negatively related to transactional psychological contract

As mentioned earlier, the impact of external HR attribution of fulfilling the basic union and regulation requirements was still arguable. Although Rousseau (2004) mentioned that social cue, environment and norms were the variables affecting psychological contract, it was hard to tell which types of psychological contract 
would be developed from that. The employees with relational contract might not concern on the requirements which should have been fulfilled, while the employees with transactional contract might perceive that the requirements were minimum but they would pursue for more. Although this attribution had impact on employment relationship, it was expected external attribution had no significant relationship with the psychological contract (Turnley, Bolino, Lester \& Bloodgood, 2004).

Hypothesis 10a: Attribution that HR practices which are designed for fulfilling the union/regulation requests will be unrelated to relational psychological contract

Hypothesis 10b: Attribution that HR practices which are designed for fulfilling the union/regulation requests will be unrelated to transactional psychological contract

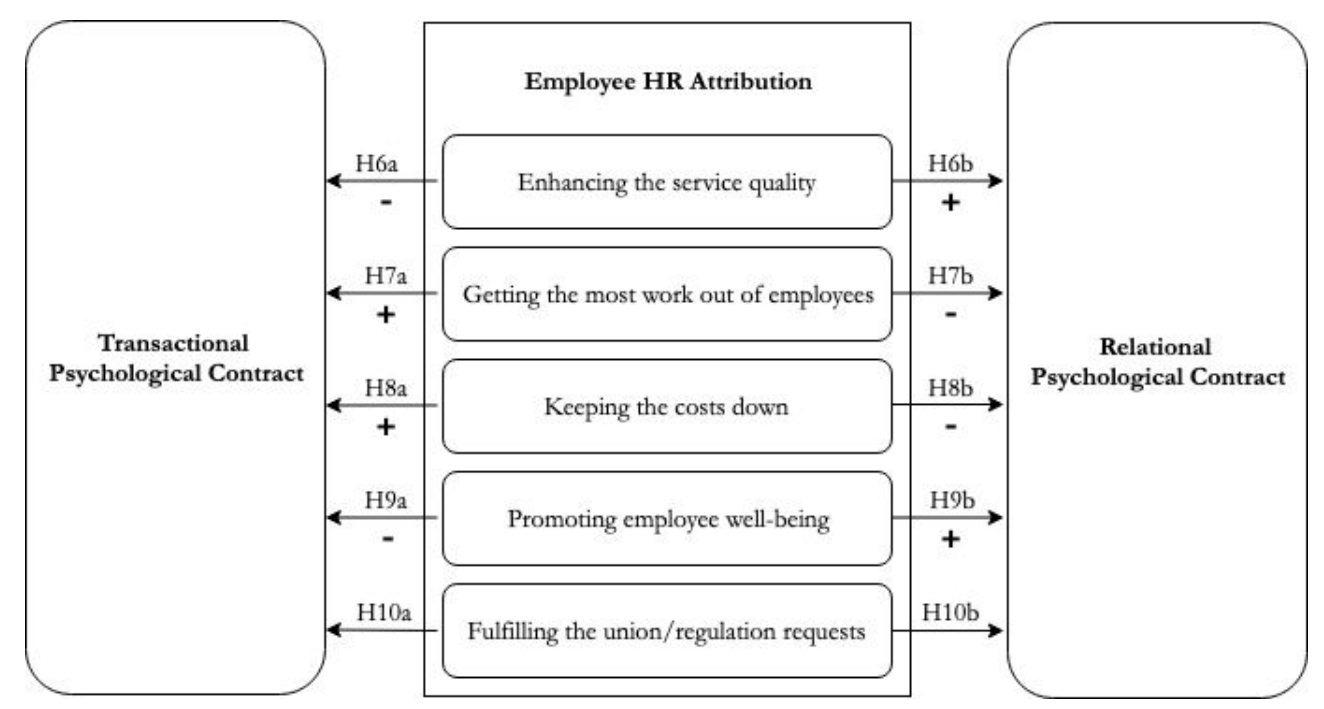

Figure 3. The hypothesized model - HR attribution \& psychological contract

\subsection{Psychological contract and turnover intention}

Empirical studies showed that psychological contract violation would result in decreasing organisational commitment and increasing turnover intention (Morrison \& Robinson, 1997; Rousseau, 2004), but only limited research focus on the different between types of psychological contract. Since organisational commitment was defined as "emotional attachment" to and "involvement" in an organisation (Meyer \& Allen, 1997), employees with relational psychological contract, who would be expected to have a high level in organisational commitment, had lower chance to quit the organisation. However, they would react emotionally, and absenteeism was likely to occur if the perceived a violation of psychological contract (Sturges et al., 2005), which might be a more serious employee outcome. On the other hand, most of the employees with transactional psychological contract, who were not expected to have a longer employment relationship, relatively had less attachment to the organisation and more intention 
to leave the organisation. If they perceived a breach of psychological contract or violation, they would react immediately such as quitting the job, as they were likely to find other job opportunities before that (Zhao et al., 2007; Welander, Astvik \& Isaksson, 2017). Based on that, the following hypotheses were proposed:

Hypothesis 11a: Employee with relational psychological contract has a lower level in turnover intention

Hypothesis 11b: Employee with transactional psychological contract has a higher level in turnover intention

\section{METHODOLOGY}

\subsection{Participants and procedure}

The data were collected from the respondents in different stages through snowball sampling. The respondents were expected to be at least 18 years old, expected to be full-time employees or employers working in Hong Kong and having at least working continuously for one year in their current organisations.

A total of 153 data sets were collected in the survey. After data screening, only 105 data sets were found complete and thus retained of the respondents, $52.4 \%$ were female, $41.0 \%$ held bachelor's degree as the highest education level, $72.4 \%$ had managerial responsibility in their jobs and approximately half of the respondents $(48.6 \%)$ had been working in the company for at least 8 years.

\subsection{Measures}

\subsubsection{HR Attribution}

Based on the literature review on the above, the respondents would answer the questions relating to HR practices and five employee HR attributions would be provided for selection in each question-enhancing the service quality $(\alpha=.83)$, getting the most works out of the employees $(\alpha=.85)$, keeping the costs down $(\alpha=$ .83), promoting employees' well-being $(\alpha=.83)$, and fulfilling the union requirements $(\alpha=.87)$. For data collection, each question would be measured in a 5-point Likert-type scale.

\subsubsection{Turnover intention}

Turnover could give a general idea of what kind of outcomes or circumstances might occur when a certain type of psychological contract was operating. As the outcome of the framework, turnover intention $(\alpha=.90)$ were designed in the survey based on the "Turnover Intention Scale" (TIS-6) which was built by Roodt in 2004 (Bothma \& Roodt, 2013) and revised by Giffen (2015). TIS-6 was selected because of its proven reliability and validity. 


\subsubsection{Psychological contract inventory (PCl)}

It was hard to determine which type of psychological contract was actually operating in the human mind (Maguire, 2003). Rousseau $(2000 ; 2008)$ designed the $\mathrm{PCl}$ to classify which type was likely operating more in an individual mind. The same author suggested multiple dimensions to define different types of psychological contracts and pointed out that researchers should focus on not only employee obligation but also employer obligation. As there were limited researches having studied the other two types psychological contract (transformational and balanced), only the items related to relational psychological contract $(\alpha=.88)$ and transactional psychological contract $(\alpha=.89)$ from $\mathrm{PCl}$ would be conducted in this study.

\section{RESULT AND DISCUSSION}

Regression analysis as one of the most widely used statistical tools for analysing data with multi variables or factors, was used in this study. A multiple linear regression was run $\left(R^{2}=0.135\right)$ to predict the turnover intention from five HR attributions. Based on that, relational psychological contract $\left(R^{2}=0.257\right)$. and transactional psychological contract $\left(R^{2}=0.283\right)$ were examined as an intervening variable in the same model separately. The results were shown in the figures. Based on the result, the hypotheses were tested and would be discussed in the next section.

Generally speaking, the result showed that employee HR attribution, psychological contract and turnover intention had direct relationship. However, not all the hypotheses were proved. Three employee HR attributions had direct relationship with turnover intention $(\mathrm{H} 1, \mathrm{H} 2, \mathrm{H} 5)$. Two employee $\mathrm{HR}$ attributions had significant relationship with relational psychological contract $(\mathrm{H} 6 \mathrm{a}, \mathrm{H} 7 \mathrm{a})$. As expected, relational psychological contract had a strong negative relationship with turnover intention $(\mathrm{H} 11 \mathrm{a})$, while transactional psychological contract had a strong positive relationship with turnover intention $(\mathrm{H} 11 \mathrm{~b})$. Besides that, there was no significant relationship between employee HR attributions and transactional psychological contract. 
The Role of Employee Human Resources Attribution on Developing

Psychological Contract and Turnover Intention in Hong Kong

(Kong Chui San)

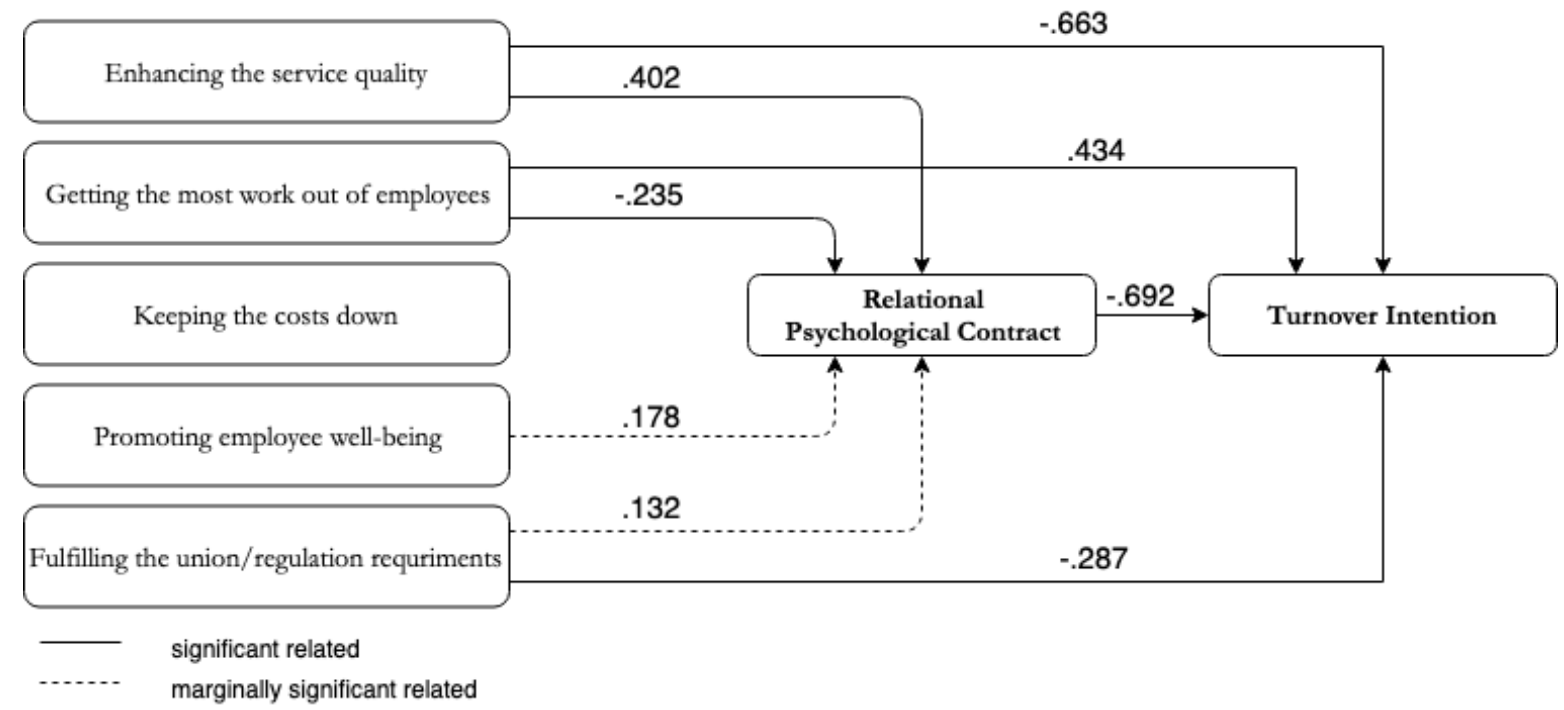

Figure 4 Specific relational model-relational psychological contract

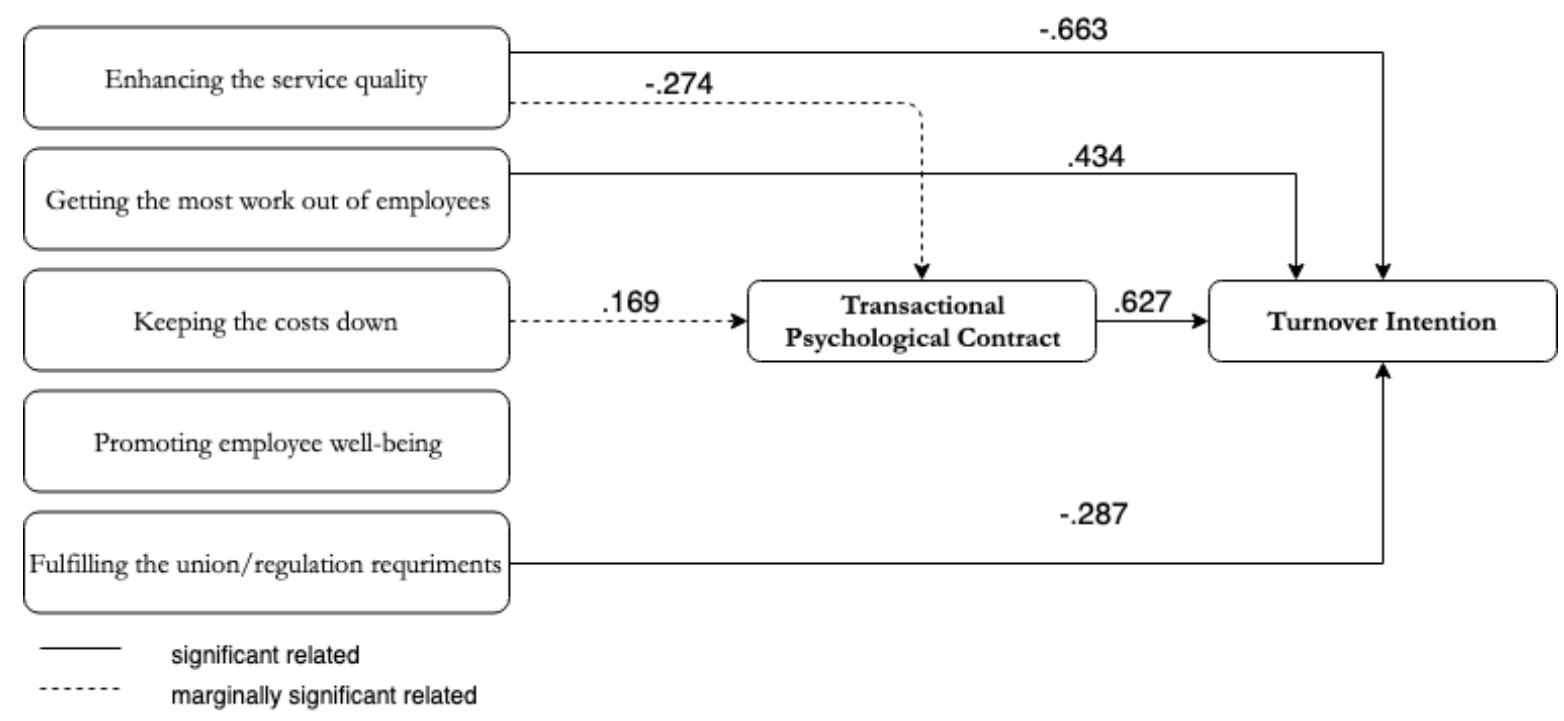

Figure 5 Specific relational model - transactional psychological contract 
Table 1. Hypotheses testing

\begin{tabular}{|c|c|c|}
\hline Hypothesis & Result & Decision \\
\hline $\mathrm{H} 1$ & Significant negative related & Accepted \\
\hline $\mathrm{H} 2$ & Significant positive related & Accepted \\
\hline H3 & Not significant related & Rejected \\
\hline $\mathrm{H} 4$ & Not significant related & Rejected \\
\hline H5 & Significant negative related & Rejected \\
\hline $\mathrm{H} 6 \mathrm{a}$ & Significant positive related & Accepted \\
\hline $\mathrm{H} 6 \mathrm{~b}$ & Not significant related ${ }^{\# 2}$ & Rejected \\
\hline $\mathrm{H} 7 \mathrm{a}$ & Significant negative related & Accepted \\
\hline $\mathrm{H} 7 \mathrm{~b}$ & Not significant related & Rejected \\
\hline $\mathrm{H} 8 \mathrm{a}$ & Not significant related & Rejected \\
\hline $\mathrm{H} 8 \mathrm{~b}$ & Not significant related ${ }^{\# 1}$ & Rejected \\
\hline $\mathrm{H} 9 \mathrm{a}$ & Not significant related ${ }^{\# 1}$ & Rejected \\
\hline $\mathrm{H} 9 \mathrm{~b}$ & Not significant related & Rejected \\
\hline $\mathrm{H} 10 \mathrm{a}$ & Not significant related ${ }^{\# 1}$ & Accepted \\
\hline $\mathrm{H} 10 \mathrm{~b}$ & Not significant related & Accepted \\
\hline $\mathrm{H} 11 \mathrm{a}$ & Significant negative related & Accepted \\
\hline $\mathrm{H} 11 \mathrm{~b}$ & Significant positive related & Accepted \\
\hline
\end{tabular}

\subsection{HR attribution and turnover intention}

The result showed that HR attribution had a great impact on turnover intention. However, instead of proving the hypothesis (H5), a surprising outcome was resulted with the only external HR attribution which actually had negative significant relationship with turnover intention. This could be explained by Turnley and others (2004) who suggested that "fulfilling union/ regulation requirements" were the basic HR practices as one of the basic criteria in an employment relationship. If the organisations did not fulfil the "basic" requirements, some employees might have negative emotion feeling as they did not get what they. However, more studies in the related areas are needed to prove that.

Lastly, no relationship was proved with the HR attribution, "keeping the costs down". It was unexpected that the result showing "keeping the costs down" was unrelated to the development of psychological contract and turnover intention. Although more studies were required to have a casual explanation of this 
phenomena, the outcome suggested that HR attribution relating to economic transaction might be unrelated with turnover intention.

\subsection{Relational psychological contract as intervening variable}

Given that relational psychological contract was proved to have negative significant relationship with turnover intention $(\mathrm{H} 11 \mathrm{a})$, relational psychological contract was proved as an intervening variable in the framework. Based on the proved hypotheses $(\mathrm{H} 1, \mathrm{H} 2, \mathrm{H} 6 \mathrm{a}, \mathrm{H} 7 \mathrm{a}, \mathrm{H} 11 \mathrm{a})$, relational psychological contract and turnover intention could be predicted from two HR attributions, "enhancing the service quality" and "getting the most work out of employees". Since the hypotheses $(\mathrm{H} 8 \mathrm{a}, \mathrm{H} 9 \mathrm{a}, \mathrm{H} 10 \mathrm{a})$ were rejected, relational psychological contract was not proved as an intervening variable between the relationship of those three particular HR attributions and turnover intention.

\subsection{Transactional psychological contract as intervening variable}

Employees with transactional psychological contract mostly had lower level in organisational commitment (Antonaki \& Trivellas, 2014), which was proved, as transactional psychological contract had significant positive relationship with turnover intention ( $\mathrm{H} 11 \mathrm{~b})$. However, transactional psychological contract was not proved as an intervening variable in the framework, as no predictor variables were proved significantly with transactional psychological contract.

\subsection{Theoretical implication}

\subsubsection{Relational and transactional psychological contract}

In the past three decades, relational and transactional were considered as the two main types of psychological contract (Chiang, Jiang, Liao \& Klein, 2012; Herriot \& Pemberton, 1996; Robinson \& Rousseau, 1994; Rousseau, 1989; 2004). Supported by many evidences, Rousseau (1995) suggested that they denoted opposite ends of a continuum as these two types had extremely different obligations in many ways. This study was designed based on this concept. So, if an employee HR attribution had positive relationship with relational psychological contract, that attribution should have negative relationship with transactional psychological contract.

Relational psychological contract had negative relationship with turnover intention, while transactional psychological contract had a totally opposite result, that it had positive relationship with turnover intention. Also, if the predictor variables having "marginally" significant relationship with psychological contract were included in the result, a predictor variable, "enhancing the service quality", supported the same statement. That particular HR attribution had positive significant relationship with relational psychological contract, while it had negative "marginally" significant relationship with transactional psychological contract. Given that, the statement mentioned above was supported, that relational and 
transactional psychological contracts were opposite ends of a bipolar continuum, as they were likely to lead to the exact opposite employee outcomes.

However, this statement was not absolutely true, as "marginally" significant relationship was still not significant proved. The result of this study also showed evidences proving that the psychological contract was not a distinct concept. Although two out of five employee HR attributions were proved to have significant relationship with relational psychological contract, the relationship between employee HR attribution and transactional psychological contract was not significant. In fact, the researchers did not reach a consensus about how many types of psychological contract existed, and whether relational and transactional were distinct concepts (Ruokolainen et al., 2018). Empirical researchers supported that there should be more than two types of psychological contract, while some suggested that an employee's psychological contract could possibly include both types (Ballou, 2013; Hui, Lee \& Rousseau, 2004).

\subsubsection{Employee HR attribution and psychological contract}

The result showed that employee HR attributions had a huge impact of the development of relational psychological contract. However, it would not increase or decrease the chance of developing a transactional psychological contract, even if the employees perceived the HR practices in a totally opposite way and had different HR attribution. As a result, it suggested that the employee HR attribution only affected the development of relational psychological contract. For the employees with transactional psychological contract, HR attribution might more likely be a push-pull factor evaluating the employment engagement and turnover (Shah, Fakhr, Ahmad \& Zaman, 2010).

\subsection{Managerial implication}

It was proved that employee HR attribution had great impact on the development of relational psychological contract, as well as turnover intention. Therefore, employers needed to put more attention on how to design the HR practices and strategies. It was suggested that the managers needed to take measures to enhance the obligation and commitment, as it did not only reduce turnover intention (Knights \& Kennedy, 2005) but also helped developing the relational psychological contract. Although it would be slightly different on what kinds of measure and HR practices should be taken based on which industry the company was in (Patrick, 2008), the focus point was suggested as how the employees perceived that and what kinds of HR attributions would be resulted to. If the employees perceived that the employers would make efforts to attract or retain them, they would be more likely to hold relational psychological contract reducing turnover intention.

On the other hand, most of the hypotheses relating to transactional psychological contract were rejected. It showed that the antecedent of transactional psychological contract might not be HR attribution as it was 
impossible to learn what kinds of HR attribution affecting transactional psychological contract from this study. Guest and Clinton (2017) suggested that employees would naturally hold transactional psychological contract if they had flexible or short-term legal contract, which were more common than before because of the change in the nature of employment and market. Nevertheless, if employees with transactional psychological contract would have higher level in turnover intention naturally, it was arguable that whether the employers needed to take measures to attract and retain the employees with transactional psychological contract.

\section{CONCLUSION}

Drawing upon the attribution theory and the concept of psychological contract, a framework was presented in this study to examine the correlation relationship between five kinds of employee HR attribution, two main types of psychological contract and turnover intention as a type of employee outcomes. A quantitative research was conducted, and 105 samples were gathered for the use of hypotheses testing. Overall, it proved that employee HR attribution had significant relationship with relational psychological contract and turnover intention, but it raised the question of how they were related. This result also suggested that relational and transactional psychological contracts were not distinct concepts, questioning how many types of psychological contract existed. The framework might be far more complicated than we previously thought and further studies should be done to clear the questions.

As limitation, there should be more factors affecting the framework that this study did not included, such as other employee outcomes and breach of psychological contract. On the other hand, it was unavoidable that the lack of sufficiently large sample size and enough reliable data would affect the result of the research because of the limitation of time and resources. In the online survey, the limited resources in executing the methodology. The majority of respondents were aged 41-50 (48.6\%), while two of them were aged over 60 . This situation showed the weakness of snowball sampling, as only certain groups of people might volunteer to participate in the study. This might lead to some bias in the result. To reduce the chance of bias and error, random sampling and sufficiently large sample size were recommended for future studies.

The practitioners need to understand the strength of psychological contract as it is highly related to the HRM and employee outcomes. Nevertheless, this study focused on the "soft" issue on psychology and behaviourism level, so it might be hard to implicate in practice. Still, expectations are mostly based on the information the employees received and perceived (Guest \& Conway, 2002), so organisations need to put more attention on how and why the employees have those expectations through HRM. 


\section{ACKNOWLEDGEMENT}

This research study was supported by so many people and I would like to express my great appreciation. I owe my sincere gratitude to Mr. Jonathan Crawshaw for his beneficial and constructive suggestion for this paper when I was conducting this research in Aston University. I am greatly indebted to him for his continuous encouragement and invaluable support. Also, I would like to vote my thank to my family and friends for their unconditional support and love.

\section{REFERENCE}

Antonaki, X. E., \& Trivellas, P. (2014). Psychological contract breach and organizational commitment in the Greek banking sector: The mediation effect of job satisfaction. Procedia-social and behavioral sciences, 148, 354361.

Arthur, D. (2001). The employee recruitment and retention handbook. New York, NY: Amacom.

Arthur, J. B. (1994). Effects of human resource systems on manufacturing performance and turnover. Academy of management journal, 37, 670-687.

Ballou, N. S. (2013). The effects of psychological contract breach on job outcomes. Master's thesis, Paper 4327. San Jose, CA: San Jose State University

Bamberger, P. A., Biron, M., \& Meshoulam, I. (2014). Human resource strategy: Formulation, implementation, and impact. New York, NY: Routledge.

Bothma, C. F., \& Roodt, G. (2013). The validation of the turnover intention scale. $S A$ journal of human resource management, 11(1), 1-12. doi:10.4102/sajhrm.v11i1.507

Bowen, D. E., \& Ostroff, C. (2004). Understanding HRM-firm performance linkages: The role of the "strength" of the HRM system. Academy of management review, 29(2), 203-221.

Chiang, J. C., Jiang, J. J. Y., Liao, C., \& Klein, G. (2012). Consequences of psychological contract violations for IS personnel. Journal of Computer Information Systems, 52(4), 78-87.

Cullinane, N., \& Dundon, T. (2006). The psychological contract: A critical review. International journal of management reviews, 8(2), 113-129.

Davila, A., \& Elvira, M. M. (2007). Psychological contracts and performance management in Mexico. International journal of manpower, 28 (5), 384-402. 
Deckop, J.R., Mangel, R. \& Cirka, C.C. (1999). Getting more than you pay for: Organizational citizenship behavior and pay-for-performance plans. Academy of management journal, 42(4), 420-428.

Gallagher, T. (2008). Exploratory study of the antecedents of psychological contract breach (Master's thesis, Cranfield University). Retrieved from http://dspace.lib.cranfield.ac.uk/handle/1826/4632

Giffen, R. (2015). Organizational culture and personality type: Relationship with person-organization fit and turnover intention (Doctoral dissertation). Graduate theses and dissertations. 14387. Retrieved from https://lib.dr.iastate.edu/etd/14387

Guest, D. (2004). The psychology of the employment relationship: an analysis based on the psychological contract. Applied psychology, 53, 541-555.

Guest, D. E., \& Clinton, M. (2017). Contracting in the UK: Current research evidence on the impact of flexible employment and the nature of psychological contracts. In Employment contracts and well-being among European workers (pp. 201-223). Routledge.

Guest, D. E., \& Conway, N. (2002). Communicating the psychological contract: An employer perspective. Human Resource Management journal, 12(2), 22-38.

Herriot, P., \& Pemberton, C., (1996). Contracting careers. Human relations, 49, 757-790.

Hesslow, G. (2002). Conscious thought as simulation of behaviour and perception. Trends in cognitive sciences, 6(6), 242-247.

Highhouse, S., Zicker, M. J., Thorsteinson, T. J., Stierwalt, S. L., \& Slaughter, J. E. (1999). Assessing company employment image: An example in the fast food industry. Personnel psychology, 52, 151-172.

Hui, C., Lee, C., \& Rousseau, D. M. (2004). Psychological contract and organizational citizenship behavior in China: Investigating generalizability and instrumentality. Journal of Applied Psychology, 89(2), 311.

Huselid, M. A. (1995). The impact of human resource management practices on turnover, productivity, and corporate financial performance. Academy of management journal, 38(3), 635-672.

Jones, E. E., \& Davis, K. E. (1965). From acts to dispositions the attribution process in person perception. In Advances in experimental social psychology (Vol. 2, pp. 219-266). Academic Press.

Kelley, H. H., \& Michela, J. L. (1980). Attribution Theory and Research. Annual review of psychology, 31(1), 457-501. 
Knights, J. A., \& Kennedy, B. J. (2005). Psychological contract violation: Impacts on job satisfaction and organizational commitment among Australian senior public servants. Applied HRM research, 10(2), 57-72.

Koys, D. J. (1988). Human resource management and a culture of respect: Effects of employees' organizational commitment. Employee rights and responsibilities journal, 1, 57-68.

Koys, D. J. (1991). Fairness, legal compliance, and organizational commitment. Employee rights and responsibilities journal, 4(4), 283-291.

Maguire, H. (2003). The changing psychological contract: challenges and implications for HRM, organizations and employees. In Human resource management: Challenges and future directions (pp. 87-103). Brisbane, QLD: John Wiley \& Sons Australia Ltd.

Mazzei, M. J., Flynn, C. B., \& Haynie, J. J. (2016). Moving beyond initial success: Promoting innovation in small businesses through high-performance work practices. Business horizons, 59(1), 51-60.

Meyer, J., \& Allen, N. (1997). Commitment in the Workplace: Theory, research and application. Thousand Oaks, CA: SAGE Publications.

Morrison, E.W., \& Robinson, S.L. (1997). When employees feel betrayed: A model of how psychological contract violation develops. Academy of management: The academy of management review, 22, 226-256.

Nishii, L. H., Lepak, D. P., \& Schneider, B. (2008). Employee attributions of the "why" of HR practices: Their effects on employee attitudes and behaviors, and customer satisfaction. Personnel psychology, 61(3), 503-545.

Oja, B. D., Wear, H. T., \& Clopton, A. W. (2018). Major sport events and psychic income: The social anchor effect. Journal of sport management, 32(3), 257271.

Patrick, H. A. (2008). Psychological contract and employment relationship. The Icfai University Journal of organizational behavior, 7(4), 7-24.

Robinson, S. L., \& Rousseau, D. M. (1994). Violating the psychological contract: Not the exception but the norm. Journal of organizational behavior, 15, 245259.

Rousseau, D. M. (1989). Psychological and implied contracts in organizations. Employee responsibilities and rights journal, 2, 121-13.

Rousseau, D. M. (1995). Psychological contracts in organizations: Understanding the written and unwritten agreements. London, England: SAGE Publications.

Rousseau, D. M. (2000). Psychological contract inventory technical report [Version 3]. 
Rousseau, D. M. (2004). Psychological contracts in the workplace: Understanding the ties that motivate. Academy of management executive, 18, 120-127.

Rousseau, D. M. (2008). Psychological contract inventory. Pittsburgh, PA: Carnegie Mellon University's Heinz College.

Ruokolainen, M., Mauno, S., Diehl, M. R., Tolvanen, A., Mäkikangas, A., \& Kinnunen, U. (2018). Patterns of psychological contract and their relationships to employee well-being and in-role performance at work: longitudinal evidence from university employees. The international journal of human resource management, 29(19), 2827-2850.

Savaneviciene, A., \& Stankeviciute, Z. (2010). The models exploring the "black box" between HRM and organizational performance. Engineering economics. 21. 426-434.

Shah, I. A., Fakhr, Z., Ahmad, M. S., \& Zaman, K. (2010). Measuring push, pull and personal factors affecting turnover intention: a case of university teachers in Pakistan. Review of economic and business studies, 3(1), 167192.

Sturges, J., Conway, N., Guest, D., \& Liefooghe, A. (2005). Managing the career deal: The psychological contract as a framework for understanding career management, organizational commitment and work behavior. Journal of organizational behavior, 26(7), 821-838.

Suazo, M. M., Martínez, P. G., \& Sandoval, R. (2009). Creating psychological and legal contracts through human resource practices: A signaling theory perspective. Human resource management review, 19(2), 154-166.

Turnley, W. H., Bolino, M. C., Lester, S. W., \& Bloodgood, J. M. (2004). The effects of psychological contract breach on union commitment. Journal of Occupational and Organizational Psychology, 77(3), 421-428.

Van De Voorde, K., \& Beijer, S. (2015). The role of employee HR attributions in the relationship between high-performance work systems and employee outcomes. Human resource management journal, 25(1), 62-78.

Welander, J., Astvik, W., \& Isaksson, K. (2017). Corrosion of trust: Violation of psychological contracts as a reason for turnover amongst social workers. Nordic social work research, 7(1), 67-79.

Wright, P. M., \& Gardner, T. M. (2003). Theoretical and empirical challenges in studying the HR practice - firm performance relationship. In Holman, D., Wall, T.D., Clegg, C., Sparrow P., \& Howard, H. (eds.). The new workplace: People technology, and organization. Sussex, England: John Wiley and Sons. 
Zhao, H. A. O., Wayne, S. J., Glibkowski, B. C., \& Bravo, J. (2007). The impact of psychological contract breach on work-related outcomes: A meta-analysis. Personnel psychology, 60(3), 647-680. 